\title{
Records of cosmopolitan myxomycetes occurring on banana litter from Southern Mindanao, Philippines
}

\author{
Prince Nur-Hakeem N. Buisan ${ }^{1}$, Zohaina M. Pasandalan ${ }^{1}$, Almera D. Pandulo ${ }^{1}$, Nof A. Balabagan ${ }^{1}$, \\ Tasmera O. Farid ${ }^{1}$, Tarhata A. Abubakar ${ }^{1}$, Athea Mohidda M. Pantog ${ }^{1}$, Datutie A. Labas ${ }^{1}$, \\ Nikki Heherson A. Dagamac ${ }^{2 *}$
}

\begin{abstract}
Banana leaf litter as a microhabitat for cosmopolitan myxomycetes has never been studied in the Philippines. Since Southern Mindanao hosts a number of local banana plantations, ground leaf litters and pseudostems were randomly collected to set up moist chamber cultures that eventually yielded plasmodial or fruiting body records. Fructifications were observed from moist chambers containing the litters from the pseudostem. Five species are reported for this study namely, Arcyria cinerea, Didymium nigripes, Didymium squamulosum, Perichaena depressa, and Perichaena vermicularis. This record calls for comprehensive investigation of agricultural plantations in the country for possible substrate association of myxomycetes.
\end{abstract}

Keywords: indigenous crops, Maguindanao, mycology, North Cotabato, plasmodia

\section{Introduction}

Studies of myxomycetes in Southeast Asia showed relatively high diversity in terrestrial ecosystem with more heterogeneity in plant communities such as tropical wet forests (Dagamac et al. 2017; Dagamac et al. 2012) and lowland coastal forests (Macabago et al. 2016; Dagamac et al. 2015) in comparison to ecosystems with homogenous plant assemblages such as reef woodland vegetation (Macabago et al. 2017) or grasslands (Carascal et al. 2017). Nonetheless, a general pattern is always visible on all of these vegetation studies: cosmopolitan myxomycetes are always expected to thrive on fast decaying organic plant material especially in the leaf litter (Rea-Maminta et al. 2015; Schnittler et al. 2017).

In the case of the Philippines, many of these leaf inhabiting myxomycetes or foliicolous myxomycetes have not been directly associated to specific plant substrates due to the following reasons: (1) the impracticality of identifying the

\footnotetext{
${ }^{1}$ Senior High School Department, Pikit National High School, Pikit, Cotabato 9409, Philippines

${ }^{2}$ Insititute of Botany and Landscape Ecology, University of Greifswald, Soldmannstr. 15, D-17487 Greifswald, Germany

*Corresponding email: nhadagamac@gmail.com

Date Submitted: 26 July 2019

Date Accepted: 11 November 2019
}

specific leaf litter that are most of the time heavily degraded making it impossible to be identified from which plant it came, (2) most litters that are found on the ground are composed of mixed leaf litter making them difficult to separate when they are randomly collected in the forest and (3) most of the rapid assessments have limited botanical knowledge. Hence, in spite of many myxomycete surveys conducted on many forest vegetation of the country, specific plant microhabitat association with myxomycetes are still comparably limited and less understood. So far, in the Philippines, leaf substrates such as in the plantation of Saccharum officinarum L. (Alfaro et al., 2015) and Imperata sp. (Carascal et al., 2017) have been reported with cosmopolitan myxomycetes. To the best of our knowledge, these are only two studies that implicitly attempted to document myxomycete on a specific plant species.

Since myxomycetes studies in Mindanao are relatively scarce (Almadrones-Reyes \& Dagamac, 2018) and no report of myxomycetes in the Philippines have accounted for banana leaf litter, this study was conducted to document for the first time the possible occurrence of myxomycetes on this particular leaf substrate.

\section{Materials and Methods}

For this study, leaf litter represented by dead ground leaves and decaying pseudostems that are still attached on the tree was randomly collected from three different banana plantations 
located in two barangays (Fig. 1) in Pikit, North Cotabato (Barangay Balong and Barangay Gocotan) and one barangay in Pagalungan, Maguindanao (Barangay Layog). After air drying for two weeks, all of the leaf litter were subjected into moist chamber cultures following the detailed procedure of Stephenson \& Stempen (1994). Each chamber was lined with tissue paper and was filled with distilled water that was soaked overnight. After $24 \mathrm{~h}$, water was thrown out of the chamber and the $\mathrm{pH}$ of each chamber was measured and was maintained under ambient light conditions for up to maximum of 8 weeks. The moist chambers were regularly checked every week for the presence of myxomycetes plasmodia and/or fruiting bodies. To keep the chambers moist, distilled water was added on certain occasions. Moist chambers that produced myxomycetes fruiting bodies were initially segregated. The substrates inside those moist chambers were then placed inside herbarium matchboxes and were cooled under freezing condition overnight to prevent insect infestation. The fruiting body characteristics (type, shape, presence of lime, height and color) were then described using a stereo microscope and were used for initial determination.. Internal structure of the fruiting bodies was also noted such as presence or absence of columella, appearance of the hypothallus, attachment to the calyculus and layers of peridium. The morphological identities of the collected myxomycetes were verified by the last author. All fruiting bodies were then preserved in the personal myxomycete collection of the first author.

\section{Results and Discussion}

From 120 moist chambers prepared, a total of 38 (31.66\%) moist chambers were positive for myxomycetes (either plasmodia / fruiting bodies) wherein the pseudostem (31) yielded more number of positive moist chambers culture than the ground leaf litter (7). High plasmodial count was not able to successfully fruit from all the moist chambers of the ground leaf litter (Fig. 2). In spite of this, 5 cosmopolitan myxomycete records are determined for this study namely, Arcyria cinerea (Bull.) Pers., Didymium nigripes (Link) Fr., Didymium squamulosum (Alb. \& Schwein.) Fr. \& Palmquist, Perichaena depressa Libert, and Perichaena vermicularis (Schwein.) Rostaf.

In comparison to previous studies in other agricultural areas of the Southeast Asian region, it seems that a common pattern appears: agricultural leaf litters having either thick leathery leaves like Dimocarpus longan Lour. and Psidium guajava L. or underneath hair-like structures like Camellia sinensis L. would produce higher fructification of cosmopolitan myxomycetes (Redeña-Santos et al., 2017) than those leaf litter characterized to have smooth surfaces like banana. Perhaps, investigations on the use of warted leaf structures as effective spore traps of cosmopolitan myxomycetes would warrant further studies. Moreover, these records of cosmopolitan myxomycetes in banana leaf litter confirmed the broad range distribution pattern of the myxomycetes in tropical Southeast Asia (Tran et al. 2008). This report about the occurrence of cosmopolitan

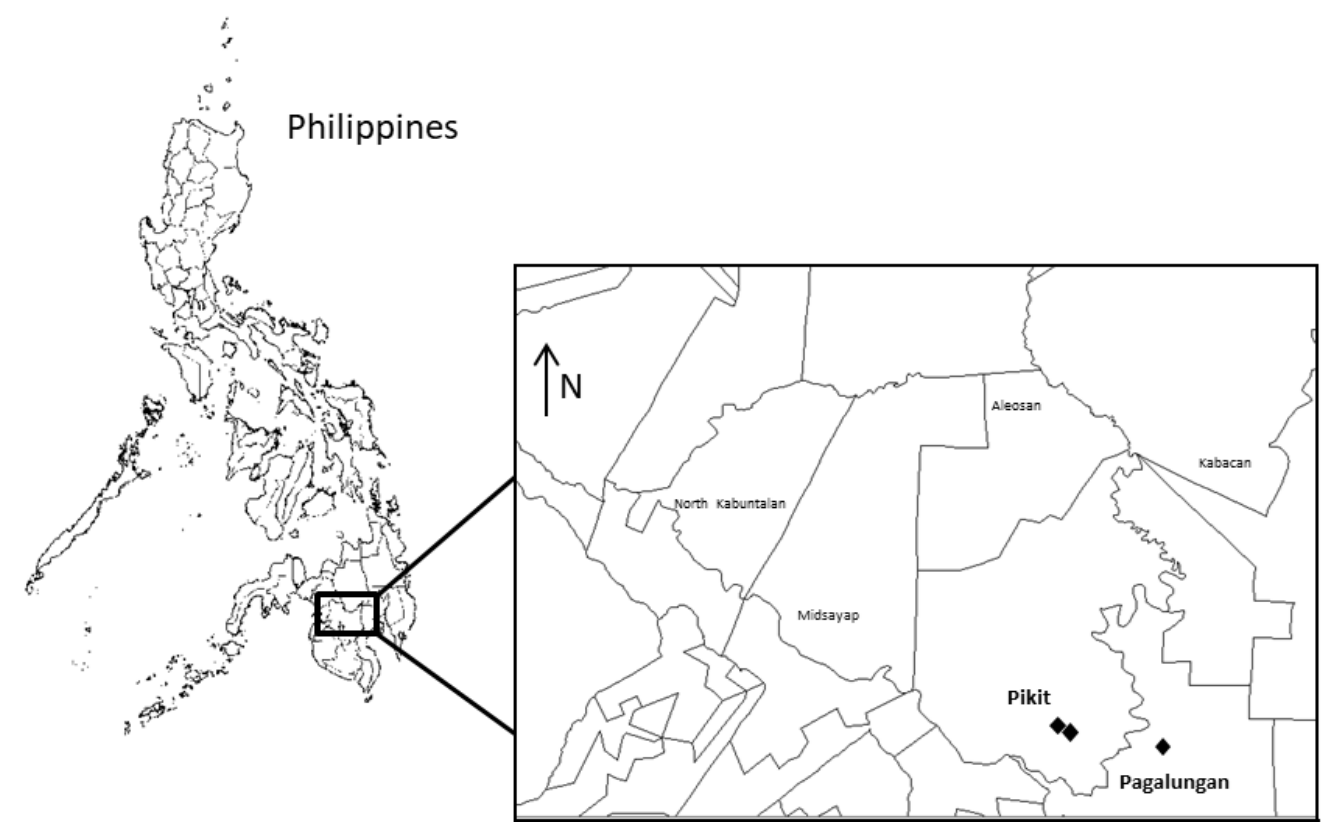

Figure 1. Collection sites in three banana plantations located in the municipalities of Pikit, North Cotabato and Pagalungan, Maguindanao 


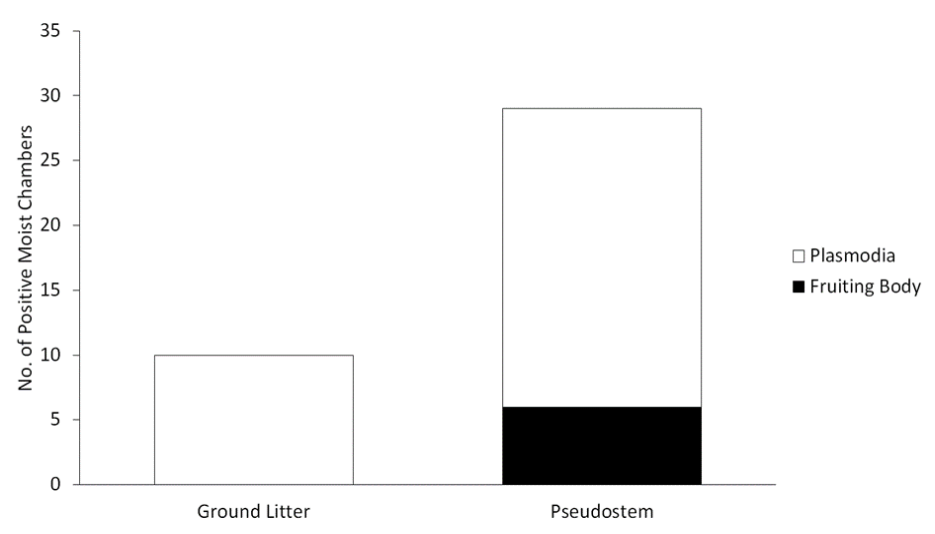

Figure 2. Productivity of myxomycetes in moist chamber cultures of different two banana substrates.

myxomycetes suggests that comprehensive diversity assessments of monotypic vegetation in the Philippines, particularly in the agriculturally rich areas of Mindanao, are feasible. Hence, it would be noteworthy to expand myxomycetes diversity studies to different and unexplored agriculture plantations in Mindanao, since there are a lot of tropical crops in many places of the region that may harbor undiscovered species of myxomycetes.

\section{Literature Cited}

Alfaro, J.R.D., Alcayde, D.L.I.M., Agbulos, J.B., Dagamac, N.H.A., dela Cruz, T.E.E. (2015). The occurrence of myxomycetes from a lowland montane forest and agricultural plantations of Negros Occidental, Western Visayas, Philippines. Fine Focus 01:07-20.

Almadrones-Reyes, K.J., Dagamac, N.H.A. (2018). Predicting local habitat suitability in changing climate scenarios: Applying species distribution modelling for Diderma hemisphaericum. Current Research in Environmental and Applied Mycology 8: 492-500.

Carascal, M.B., Rea, M.A.D., Dagamac, N.H.A., dela Cruz, T.E.E. (2017). Myxomycetes associated with grassland litter of the Philippines. Current Research in Environmental \& Applied Mycology 7(2):56-63.

Dagamac, N.H.A., dela Cruz, T.E.E., Rea-Maminta, M.A.D., Aril-dela Cruz, J.V., Schnittler M. (2017). Rapid assessment of myxomycete diversity in the Bicol Peninsula, Philippines. Nova Hedwigia 104 (1-3): 31-46.

Dagamac, N.H.A., Rea-Maminta, M.A.D., Batungbacal, N.S., Jung, S.H., Bulang, C.R.T., Cayago, A.G.R., dela Cruz, T.E.E. (2015). Diversity of plasmodial slime molds (myxomycetes) on coastal, mountain and community forests of Puerto Galera, Oriental Mindoro,
Philippines. Journal of Asia-Pacific Biodiversity 8: 322 329.

Dagamac, N.H.A., Stephenson, S.L., dela Cruz, T.E.E. (2012). Occurrence, distribution, and diversity of myxomycetes (plasmodial slime molds) along two transects in Mt. Arayat National Park, Pampanga, Philippines. Mycology 3(2): 119 126.

Macabago, S. A.B., Stephenson, S.L., dela Cruz, T.E.E. (2016). Diversity and distribution of myxomycetes in coastal and mountain forests of Lubang Island, Occidental Mindoro, Philippines. Mycosphere 7(1): 18-29.

Macabago, S.A.B., Dagamac, N.H.A., dela Cruz, T.E.E., Stephenson, S.L. (2017). Implications of the role of dispersal on the occurrence of litter-inhabiting myxomycetes in different vegetation types after a disturbance: A case study in Bohol Island, Philippines. Nova Hedwigia 104(1-3): 221-236.

Rea-Maminta, M.A.D., Dagamac, N.H.A., Huyop, F.Z., Wahab, R.A., dela Cruz, T.E.E. (2015). Comparative diversity and heavy metal biosorption of myxomycetes (slime molds) from forest patches on ultramafic and volcanic soils. Chemistry and Ecology 31 (8): 741-753.

Redeña-Santos, J.C., Dunca, J.A.U., Duong, V.T., Dagamac, N.H.A. (2017) Myxomycetes occurring on selected agricultural leaf litter. Studies in Fungi 2: 171-177.

Schnittler, M., Dagamac, N.H.A., Novozhilov, Y.K. (2017). Biogeographical patterns in myxomycetes. In Myxomycetes: Biology, Systematics, Biogeography, Ecology. Eds: SL Stephenson \& C Rojas, Academic Press UK. pp. 299-331.

Stephenson SL, Stempen H. (1994). Myxomycetes: A Handbook of Slime Moulds. Portland Oregon: Timber Press.

Tran H.T.M., Stephenson S.L., Hyde K.D., Mongkolporn O. (2008) Distribution and occurrence of myxomycetes on agricultural ground litter and forest floor litter in Thailand. Mycologia 100: 181-190. 